\title{
BIOLOGICAL TOMATO SEED TREATMENT AND APPLICATION OF SOME FERTILIZERS TO CONTROL FUSARIUM ROOT- ROT
}

\author{
M.M. El-Hamady*; Eisa, Nour-Jehan, M.M.**and Ghada Abd-El-Ghani \\ El-Kolaly** \\ * Plant Production Department. Vegetables Branch, Efficient Productivity \\ Institute, Zagazig University, Egypt. \\ **Plant Path. Research, Institute, Agriculture Research Center, Cairo, Egypt.
}

\section{ABSTRACT}

Both Trichoderma viride and Bacillus subtilis inhibited the linear growth of Fusarium solani (Mart) Sny. And Hans, the causal agent of tomato root-rot disease. T. viride showed greater inhibitory effect compared with B. subtilis.

Greenhouse and field experiments indicated that seed coating with either T. viride or B. subtilis were effective biocontrol treatments against Fusarium root-rot of tomato. On the other hand, these treatments were found to be responsible for the increasing both fresh and dry weights of tomato shoots and roots. Furthermore, the population density of the isolated bacteria, fungi and Fusarium spp., were lower in the plants developed from treated seeds.

Different fertilizers, i.e. ammonium nitrate, calcium super phosphate, potassium sulphate and the combination among them in various rates in greenhouse experiments, significantly decreased the percentage of post-emergence damping-off caused by $F$. solani. However, the lowest percentages occurred in $N_{0} P_{1} K_{2}, N_{1} P_{1} K_{2}$ and $N_{1}$ $P_{2} K_{1}$ treatments.

On the other, most fertilizer treatments, significantly increased the number of healthy survival plants and tomato yield in the field. The highest percentages of healthy plants and yield were recorded with the application of $\mathrm{N}_{2} \mathrm{P}_{2} \mathrm{~K}_{2}(100 \mathrm{Kg}$ ammonium nitrate $+200 \mathrm{Kg}$ calcium super phosphate $+100 \mathrm{Kg}$ potassium sulphate ).

Key words: Tomato (Lycopersicon esculentum, Mill.), biological, fertilizer amounts, Fusarium root-rot, disease severity index $(D S I)$. 


\section{INTRODUCTION}

Tomato (Lycopersicon esculentum, Mill). Is considered the main glasshouse crop in most European countries. While, in Egypt, it is one of the most important vegetables crops. Tomato fruits have a high nourishing value, as it contains a considerable amounts of nutrients, vitamins and mineral salts, (Moursy and El-Morabaa, 1960). The estimated total production produced from commercial tomatoes grown in approximately 599615 feddans was 10.278 .539 tons in 2009. The Egyptian government is pressing hard to increase tomato production to face the increase our exportation.

Several diseases attack tomato plants causing serious losses in either nurseries or field conditions. For instance, Fusarium spp., Rhizoctonia sp., Pythium spp., Phytophthora spp. And Selerotium rolfsii, attack the root and stem base of tomato plants, causing root and stem rots (Moursy and El-Morabaa, 1960; Grinstein et al., 1979; El-Mougy 1995;Ghanem, 1998 and Kokalis-Burelle and Gransnamanickam, 2002). Fusarium root-rot has increased considerably in Egypt. It causes high damage in tomato cultivations especially in old lands of Egypt (El-Fahham,1993).

Biological control has recently become one of the most important methods for controlling many fungal diseases particularly tomato root-rot (ElEraky et al., 1993; El-Fahham, 1993; Roberti et al.; 1993; Hamed, 1996 and Montealegre et al., 2002).

Many investigators strongly have reported the importance of using macro elements fertilizers in reducing tomato root-rot disease (Dubey, 1958; Moursy and El-Morabaa, 1960; Duffy and Defago, 1999 and Cheuk et al., 2003). Using fertilizer applications; Kokalis-Burelle and Gransnamanickam (2002) found that supplementing soil nitrogen increased root-rot disease on tomato. In addition, Garrett (1941) recommended that a generous supply of plant nutrition probably may increase plant resistance chiefly by promoting more rapid production of new roots to replace those destroyed by the disease. Also, Blair (1943) noticed that the addition of nitrogen to the soil had not increased the growth of $R$. solani. Dubey (1958),Papavizas and Davey (1962) found that the high nitrogen application decreased the disease incidence. On the other hand, Moursy and ElMorabaa (1960) showed that potassium and phosphorus fertilizers increased the root growth of plants. This research aimed to study the effect of biological tomato seed treatment and application of some fertilizers for arriving to the best methods to control tomato root-rot disease for safe and pollution free tomato production. 


\section{MATERIALS AND METHODS}

Certain antagonists, i.e. Trichoderma viride, and Bacillus subtilis, were used in laboratory, greenhouse and field experiments to evaluate their effectiveness against Fusarium root-rot of tomato (cv. Castle Rock). Antagonistic microorganisms used in this study were isolated from rhizosphere region of tomato plants. The isolates of Fusarium solani were obtained from tomato plants cultivated in Fayoum governorate. On the other hand, Vitavax T (Vitavax $37.5 \%+37.5 \%$ Thiram) was used to compare its efficiency with the tested microorganisms.

In vitro, studies were carried out to select the most effective antagonistic microorganisms that could be applied in both greenhouse and open field. The antagonistic organisms were separately tested against Fusarium solani on potato dextrose agar medium (PDA) using the inhibition zone technique. Cultures were examined after one week of incubation. Experiments were carried out in four replicates. The antagonistic efficiency criterion was estimated by the presence or absence of an inhibition zone, as well as its length.

In the greenhouse trials, seeds were soaked in the spore suspension of Trichoderma viride or bacterial suspension of Bacillus subtilis, then sown in soil artificially infested with Fusarium solani (loamy clay soil pH 7.6 and moisture holding capacity $35 \%$ ) using $25 \mathrm{~cm}$ diameter pots, kept $20 \pm 4^{0} \mathrm{C}$, all treatments were carried out in completely randomized design with four replicates.

Inoculum applied to seeds was prepared by growing $T$. viride on PDA for 2 weeks at $25^{\circ} \mathrm{C}$ and B. subtilis on PDA + peptone $5 \%$ for I week at $25^{\circ} \mathrm{C}$. The antagonistic microorganisms were apllied to seed at the rate of 2 Petri plates (9 $\mathrm{cm}$ in diameter) $/ 10 \mathrm{~g}$ seeds. Vitavax $\mathrm{T}$ was used at the rate of $2 \mathrm{~g} / \mathrm{kg}$ of seeds. Seeds screened for the control treatments were similarly treated, but without coating with the fungicides. In field trials, seeds were soaked with the tested microorganisms as mentioned before and planted in the field (loamy clay soil, $\mathrm{pH} 7.6$ and moisture holding capacity $35 \%$ ) in which the pathogen of tomato root-rot was naturally established.

Field experiments were designed in a complete randomized block design in the farm of Fayoum Research Station in two successive seasons; 2008 and 2009.

Disease severity index (DSI) of root-rot was recorded based on a scale from 0 (non visible damage) to 4 (complete destruction), 12 weeks after planting according to Lewis and Papavizas (1977). Also, fresh and dry weights of both tomato shoots and roots were estimated at the same time. Analysis of variance was performed and means were compared by using the least significant differences at $5 \%$ level.

The population density of bacteria, Fusarium spp. And other fungi was estimated per gram of soil. These estimations were carried out on 3 replicates at 
the three stages of plant growth, I.e. seedling, vegetative and flowering stages (30, 60 and 90 days after planting, respectively) in the rhizosphere of tomato plants.

The fertilizer experiments included 12 treatments (Table 1), each treatment was replicated four times and occupied $1 / 50$ feddan (each replicate contained three rows with 25 hills). Four seeds of tomato plants (Castle Rock cv.) were planted in each hill on the second half of October of each year. Half of the fertilizer amounts of each treatment was added before the first irrigation, and the other half was added at the time of flowering.

Table 1. Amounts of fertilizers added in each pot (in gm) and in the open field (in $\mathrm{kg} /$ feddan).

\begin{tabular}{|c|c|c|c|c|c|c|}
\hline \multirow{3}{*}{$\begin{array}{l}\text { Fertilizer } \\
\text { amounts }\end{array}$} & \multicolumn{6}{|c|}{ Fertilizers } \\
\hline & \multicolumn{2}{|c|}{$\begin{array}{c}\text { Ammonium nitrate } \\
(\mathrm{N})\end{array}$} & \multicolumn{2}{|c|}{$\begin{array}{c}\text { Calcium } \\
\text { superphosphate } \\
(\mathbf{P}) \\
\end{array}$} & \multicolumn{2}{|c|}{$\begin{array}{c}\text { Potassium sulphate } \\
\text { (K) }\end{array}$} \\
\hline & Kg/feddan & g/pot & Kg/feddan & g/pot & Kg/feddan & g/pot \\
\hline \multirow{12}{*}{$\begin{array}{r}N_{1} P_{1} K_{1} \\
N_{1} P_{2} K_{1} \\
N_{1} P_{1} K_{2} \\
N_{1} P_{2} K_{1} \\
N_{2} P_{1} K_{1} \\
N_{2} P_{2} K_{1} \\
N_{2} P_{2} K_{2} \\
N_{0} P_{1} K_{2} \\
N_{0} P_{2} K_{1} \\
N_{0} P_{1} K_{1} \\
N_{0} P_{2} K_{2} \\
C o n t r o l \\
\left(N_{0} P_{0} K_{0}\right)\end{array}$} & 50 & 0.42 & 100 & 0.32 & 50 & 0.42 \\
\hline & 50 & 0.42 & 200 & 0.66 & 50 & 0.42 \\
\hline & 50 & 0.42 & 100 & 0.32 & 100 & 0.84 \\
\hline & 50 & 0.42 & 200 & 0.66 & 50 & 0.42 \\
\hline & 100 & 0.84 & 100 & 0.32 & 50 & 0.42 \\
\hline & 100 & 0.84 & 200 & 0.66 & 50 & 0.42 \\
\hline & 100 & 0.84 & 200 & 0.66 & 100 & 0.84 \\
\hline & 0 & 0 & 100 & 0.32 & 100 & 0.84 \\
\hline & 0 & 0 & 200 & 0.66 & 50 & 0.42 \\
\hline & 0 & 0 & 100 & 0.32 & 50 & 0.42 \\
\hline & 0 & 0 & 200 & 0.66 & 100 & 0.84 \\
\hline & 0 & $\mathbf{0}$ & $\mathbf{0}$ & $\mathbf{0}$ & $\mathbf{0}$ & $\mathbf{0}$ \\
\hline
\end{tabular}

Plants were counted twice, i.e. after complete emergence, and before harvest to calculate the percentage of emergence and healthy survival plants. Fruit yield of tomato plants was also determined.

\section{RESULTS AND DISCUSSION}

\section{In vitro studies:}

Data shown in Table (2) indicated that, there was antibiotic effect among the tested microorganisms and the causal pathogen. The greatest inhibitory effect was observed in the case of $T$. viride (5.2 cm inhibition zone) comparing with $B$. subtilis (3.1 cm inhibition zone). Trichoderma viride inhibited and overgrew the 
Table 2. Mean inhibition zones among the two antagonists Trichoderma viride and Bacillus subtilis, and the Fusarium solani.

Treatments

$\begin{array}{lc}\text { 1. } T \text {. viride } & 5.2 \\ \text { 2. B. subtilis } & 3.1 \\ \text { 3. Control ( F. solani alone ) } & 0.0\end{array}$

3.1
Mean inhibition zones (cm)

0.0

L.S.D. at 5\% 1.4

growth of $F$. solani, whereas $B$. subtilis only inhibited the growth of the tested pathogens.

The obtained results may have an important approach, respect to the usage of antagonistic microorganisms and their effectiveness against $F$. solani, to control a root-rot disease of tomato. Similar results were reported by Elad et al. (1982), Filippi et al. (1987), El-Fahham, (1993) and Roberti et al.(1993).

The above authors suggested that the biological behaviour may be due to the three mechanisms; secretion of antibiotics by the antagonist, mycoparasitism and lyses of mycelium of the parasite. They also emphasized that these mechanisms were probably the most important ones for controlling the causal pathogens. Also, there was an in vitro evidence of a positive relationship between the decrease in the severity of the disease and the magnitude of the inhibition zone between the antagonist and the causal fungus finally controlling this pathogen.

\section{Greenhouse studies:}

The two antagonistic microorganisms; $T$. viride and $B$. subtilis were active in the rhizosphere of tomato plants and inhibited Fusarium root-rot of tomato (Table 3). Application of the two antagonistic microorganisms, as well as the use of Vitavax T. fungicide; resulted in a sharp decrease in root-rot decrease severity, expressed as the lower disease severity index (DSI), compared with the control. Since the disease severity index were; 1.7, 1.2 and 1.2 in the infested soil, when the tomato seeds were previously treated with the two antagonistic microorganisms; $T$. viride and $B$. subtilis and the fungicide; Vitavax $T$, respectively. While, this disease index was found to be significantly higher (3.7) in the tomato plants resulted from the control untreated seeds.

Data in Table (3) were confirmed by those of El-Eraky et al. (1993) and Abd El-Moiety and Abo-Zeid (1988). They reported that Vitavax, Benlate and Brassicol completely inhibited the growth of $R$. solani. The present results are in parallel with the findings of the mentioned investigators, since they reached to the conclusion that using of T. harzianum and Bacillus subtilis as seed and/or 
Table 3. Effect of certain antagonistic microorganisms compared with Vitavax T on disease severity index (DSI) of Fusarium root-rot of tomato, under greenhouse conditions.

\begin{tabular}{|c|c|c|c|}
\hline \multirow{2}{*}{ Treatments } & \multicolumn{3}{|c|}{ Disease severity index ( DSI ) } \\
\hline & Non-infested soil & Infested soil & \\
\hline T. viride & 0.2 & 1.7 & \\
\hline B. subtilis & 0.0 & 1.2 & \\
\hline Vitavax/Thiram & 0.0 & 1.2 & \\
\hline Control & 0.5 & 3.7 & \\
\hline L.S.D.5\% & 0.05 & & 0.9 \\
\hline
\end{tabular}

soil treatments for the control of root-rot caused by Fusarium sp., under field conditions performed the best results. Similar results were also obtained by Hamed (1996) and Montealegre et al. (2002) in their previous studies.

\section{Field studies:}

The effect of the two antagonistic microorganisms; $T$. viride and $B$. subtilis, compared with Vitavax $\mathrm{T}$, on Fusarium root-rot disease severity, was studied under field conditions in the two seasons; 2008 and 2009. The obtained results showed that, the disease severity index (DSI) decreased significantly in seeds treated with the tested microorganisms; $T$. viride and B. subtilis. It was 1.0 and 1.7 in 2008 and 1.2 and 1.0 in 2009, for the two antagonistic microorganisms, respectively. Vitavax $\mathrm{T}$ was also effective in reducing the disease severity of Fusarium root-rot to a level of 0.7 in the two seasons of the study (Table 4).

Plant growth, as indicated by the average of fresh and dry weights of shoots and roots per plant, increased significantly by coating seeds with the two tested antagonistic microorganisms. Data in Table (4) suggested that some microorganism products stimulated plant growth. In the same time, the two antagonistic microorganisms reduced population density of plant pathogens. Therefore, the reduction in disease severity may be due to the low level of Fusarium population in the rhizosphere and the surrounding soil of tomato roots (Table 5).

On the other hand, the population density of rhizospheric micro flora was low at the first growth stages of plants developed from treated seeds, but they increased progressively with plant growth. (Table 5). Papavizas et al. (1968) stated that, from the voluminous accumulated rhizospheric data which support the presence of antagonism in soil, it is reasonable to believe that antagonism is an important factor affecting the population density and survival of the pathogens in the rhizosphere. 
Table 4. Effect of certain antagonistic microorganisms compared with Vitavax T, on Fusarium root-rot disease severity index (DSI) and on average fresh and dry weights of both shoots and roots of tomato plants under field conditions in 2008 and 2009.

\begin{tabular}{|c|c|c|c|c|c|c|c|c|c|c|}
\hline \multirow{3}{*}{ Treatments } & \multicolumn{5}{|c|}{ Season 2008} & \multicolumn{5}{|c|}{ Season 2009} \\
\hline & \multirow{2}{*}{ DSI } & \multicolumn{2}{|c|}{ Shoots } & \multicolumn{2}{|c|}{ Roots } & \multirow{2}{*}{ DSI } & \multicolumn{2}{|c|}{ Shoots } & \multicolumn{2}{|c|}{ Roots } \\
\hline & & F. W. & D. $\mathbf{W}^{* *}$ & F. $\mathbf{W}^{*}$ & D. $W^{* *}$ & & F. $\mathbf{W}^{*}$ & D. $\mathbf{W}^{* *}$ & F. $\mathbf{W}^{*}$ & D. $W^{* *}$ \\
\hline T. viride & 1.0 & 183.7 & 17.5 & 22.2 & 3.7 & 1.2 & 264.2 & 30.7 & 30.2 & 7.2 \\
\hline B. subtilis & 1.7 & 158.5 & 15.5 & 18.0 & 2.0 & 1.0 & 34.0 & 51.7 & 39.2 & 8.0 \\
\hline Vitavax $T$ & 0.7 & 229.7 & 22.2 & 27.0 & 5.0 & 0.7 & 377.2 & 66.5 & 43.7 & 10.7 \\
\hline Control & 2.7 & 78.5 & 11.2 & 16.7 & 1.8 & 3.2 & 213.5 & 29.2 & 25.2 & 5.2 \\
\hline $\begin{array}{l}\text { L,S.D.D } \\
\text { at } 5 \%\end{array}$ & 1.0 & 5.1 & 5.8 & 6.9 & 1.2 & 0.8 & 6.8 & 6.9 & 10.7 & 2.5 \\
\hline
\end{tabular}

F.W. = Fresh weight / g., D.W. = Dry weight g.

DSI $=$ Disease severity index .

Some bacteria increased plant growth, by the production of gibberellin or auxin of soluble phosphate, while others have been shown to alter the rhizosphere microbial flora (Filippi et al., 1987).

Therefore, the prime purpose of biological control of tomato rootrot disease was not only to raise the plant growth and yield, but also to reduce density of soil-borne pathogens, so taking all factors into consideration and the difficulties involved.

Effect of different levels of fertilizers on diseases incidence:

Different levels of fertilizers were used as shown in Table (1). The effect of different levels of nitrogen, phosphorus and potassium fertilizers on disease incidence, was studied under the greenhouse and field conditions.

\section{a. Greenhouse experiment:}

All fertilization treatments significantly decreased the percentage of post emergence damping-off caused by $F$. solani. However, the lowest percentage of post-emergence damping off was obtained by $\mathrm{N}_{0} \mathrm{P}_{1} \mathrm{~K}_{2}$ followed by $\mathrm{N}_{1} \mathrm{P}_{1} \mathrm{~K}_{2}$ and $\mathrm{N}_{1} \mathrm{P}_{2} \mathrm{~K}_{1}$ treatments (Table 6). It was; $18.5 \%, 18.9 \%$ and $20.7 \%$ for the three treatments, respectively. 
Table 6. Effect of different levels of fertilizers on tomato root-rot disease incidence caused by $F$. solani, under greenhouse conditions.

\begin{tabular}{lcc}
\hline & \multicolumn{2}{c}{ Disease incidence percentages of } \\
\cline { 2 - 3 } Treatment & Post-emergence damping-off & Survival plants \\
\hline $\mathbf{N}_{\mathbf{1}} \mathbf{P}_{\mathbf{1}} \mathbf{K}_{\mathbf{1}}$ & 32.5 & 24.0 \\
$\mathbf{N}_{\mathbf{1}} \mathbf{P}_{\mathbf{2}} \mathbf{K}_{\mathbf{1}}$ & 20.7 & 28.0 \\
$\mathbf{N}_{\mathbf{1}} \mathbf{P}_{\mathbf{1}} \mathbf{K}_{\mathbf{2}}$ & 18.9 & 30.5 \\
$\mathbf{N}_{\mathbf{1}} \mathbf{P}_{\mathbf{2}} \mathbf{K}_{\mathbf{2}}$ & 63.7 & 21.5 \\
$\mathbf{N}_{\mathbf{2}} \mathbf{P}_{\mathbf{1}} \mathbf{K}_{\mathbf{1}}$ & 42.5 & 24.5 \\
$\mathbf{N}_{\mathbf{2}} \mathbf{P}_{\mathbf{2}} \mathbf{K}_{\mathbf{1}}$ & 31.4 & 30.2 \\
$\mathbf{N}_{\mathbf{2}} \mathbf{P}_{\mathbf{2}} \mathbf{K}_{\mathbf{2}}$ & 38.0 & 20.5 \\
$\mathbf{N}_{\mathbf{2}} \mathbf{P}_{\mathbf{1}} \mathbf{K}_{\mathbf{2}}$ & 29.6 & 26.5 \\
$\mathbf{N}_{\mathbf{0}} \mathbf{P}_{\mathbf{1}} \mathbf{K}_{\mathbf{1}}$ & 28.3 & 27.5 \\
$\mathbf{N}_{\mathbf{0}} \mathbf{P}_{\mathbf{1}} \mathbf{K}_{\mathbf{2}}$ & 18.5 & 28.5 \\
$\mathbf{N}_{\mathbf{0}} \mathbf{P}_{\mathbf{2}} \mathbf{K}_{\mathbf{2}}$ & 27.0 & 24.5 \\
$\mathbf{C o n t r o l}\left(\mathbf{N}_{\mathbf{0}} \mathbf{P}_{\mathbf{0}} \mathbf{K}_{\mathbf{0}}\right)$ & 70.0 & 18.0 \\
\hline L.S.D at 5\% & $\mathbf{2 3 . 0}$ & $\mathbf{1 2 . 4}$ \\
\hline
\end{tabular}

\section{b. Field experiments:}

Results of the two field experiments are presented in Table (7), it is clear that all fertilizer treatments significantly increased the healthy survival plants as well as the yield, over the control, except treatments of $\mathrm{N}_{2} \mathrm{P}_{1} \mathrm{~K}_{2}$ in 2008 with regard to the percentage of surviving plants and $\mathrm{N}_{0} \mathrm{P}_{1} \mathrm{~K}_{2}$ regarding the yield only.

The highest percentage of healthy survival plants and yield were obtained by application of $\mathrm{N}_{2} \mathrm{P}_{2} \mathrm{~K}_{2}$. Similar results were also gained during 2009.

These results are in harmony with those obtained by many investigators such as Garrett (1941) who recommended that a generous supply of plant nutrition probably increased plant resistance chiefly by promoting more rapid production of new roots to replace those destroyed by the disease Blair (1943) noticed that the addition of nitrogen to the soil did not increase the growth of Rhizoctonia solani. While, Moursy and ElMorabaa (1960) showed that potassium and phosphorus fertilizers increased the root growth of plants. Also, Dubey (1958) and Papavizas and Davey (1962) observed that high nitrogen application decreased the root-rot disease incidence. In conclusion, the obtained results demonstrated the importance of fertilizers in reducing root-rot disease of tomato. 
Table 7. Effect of some fertilizer treatments on the root-rot disease incidence and yield of tomato, under field conditions during 2008 and 2009 seasons.

\begin{tabular}{ccccc}
\hline \multirow{2}{*}{ Treatments } & \multicolumn{2}{c}{$\mathbf{2 0 0 8}$} & \multicolumn{2}{c}{$\mathbf{2 0 0 9}$} \\
\cline { 2 - 5 } & $\begin{array}{c}\text { \% Survival } \\
\text { Plants(\%) }\end{array}$ & $\begin{array}{c}\text { Dry yield } \\
\text { (Kg/pot) }\end{array}$ & $\begin{array}{c}\text { Survival } \\
\text { plants (\%) }\end{array}$ & $\begin{array}{c}\text { Dry yield } \\
\text { (Kg/pot) }\end{array}$ \\
\hline $\mathrm{N}_{1} \mathrm{P}_{1} \mathrm{~K}_{1}$ & 37.6 & 2.200 & 76.1 & 2.162 \\
$\mathrm{~N}_{1} \mathrm{P}_{2} \mathrm{~K}_{1}$ & 38.1 & 2.362 & 78.6 & 2.312 \\
$\mathrm{~N}_{1} \mathrm{P}_{1} \mathrm{~K}_{2}$ & 38.7 & 2.400 & 81.4 & 2.437 \\
$\mathrm{~N}_{1} \mathrm{P}_{2} \mathrm{~K}_{2}$ & 38.6 & 2.525 & 85.5 & 2.437 \\
$\mathrm{~N}_{2} \mathrm{P}_{1} \mathrm{~K}_{1}$ & 32.2 & 1.812 & 72.2 & 2.072 \\
$\mathrm{~N}_{2} \mathrm{P}_{2} \mathrm{~K}_{1}$ & 37.4 & 2.312 & 82.6 & 2.425 \\
$\mathrm{~N}_{2} \mathrm{P}_{1} \mathrm{~K}_{2}$ & 30.3 & 2.050 & 77.4 & 2.150 \\
$\mathrm{~N}_{2} \mathrm{P}_{2} \mathrm{~K}_{2}$ & 42.0 & 3.042 & 87.6 & 3.925 \\
$\mathrm{~N}_{0} \mathrm{P}_{1} \mathrm{~K}_{2}$ & 32.7 & 0.875 & 83.5 & 2.062 \\
$\mathrm{~N}_{0} \mathrm{P}_{1} \mathrm{~K}_{1}$ & 37.0 & 2.025 & 84.9 & 2.425 \\
$\mathrm{~N}_{0} \mathrm{P}_{2} \mathrm{~K}_{1}$ & 37.3 & 2.025 & 85.9 & 2.462 \\
Control N $\mathrm{K}$ & 31.5 & 1.475 & 70.8 & 2.062 \\
\hline LSD at 5\% & $\mathbf{2 . 2}$ & $\mathbf{0 . 4 7 5}$ & $\mathbf{1 0 . 0}$ & $\mathbf{0 . 4 6 2}$ \\
\hline
\end{tabular}

Also, these results are in harmony with the works of Duffy and Defago (1999) who concluded that disease severity of tomato root-rot was reduced by ammonium nitrate. On the other side, Cheuk et al. (2003) found significant reductions in tomato root-rot disease and improved crop yield with the addition of compost.

Conclusively, from these results recommended that tomato is one of the most important vegetable plants in Egypt and in order to reduce the harmful influence of organisms that cause root-rot of tomatoes must use anti-vital transactions and also use a combination of fertilizer in line with the rapid growth of the roots of tomato in order to give the highest productivity in the vegetative growth and fruit yield.

\section{REFERENCES:}

Abd El-Moiety, T.H. and N.M. Abo-Zeid (1988). Effect of Trichoderma harzianum as seed dresser on lintel. Abstract of the second international Trichoderma and Gliocladium Workshop, Oxford Univ., England, 6p.

Blair, Y.D. (1943). Behaviour of the fungus R. solani Kuhn. In the soil. Ann. Appl, Biol., 30: 118. 
Cheuk, W.; Lo-Kv ; R. Branion ; B. Fraser ; R. Copeman and P. Jolliffe (2003). Applying compost to suppress tomato diseases. Biocycle, 44:1, 50-51.

Dubey, H.D. (1958). Relation of soil texture and occurrence of root-rot disease (Sclerotium rolfsii) of peanut. Plant Dis. Reptr., 42: 1376. (Rev. Appl MYCOL., 38: 438).

Duffy, B.K. and G. Defago (1999). Macro and Micro element fertilizers influence the severity of Fusarium crown and root-rot of tomato in a soilless production system. Hortiscience, 43:2, 287-291.

Elad, Y,; L. Hadar ; I. Chet and Y. Henis (1982). Prevention with Trichoderma harzianum Rifai agar of reinfestation by Sclerotium rolfsii Sacc. And Rhizoctonia solani Kuhn. of soil fumigated with methyl bromide and improvement of disease control in tomatoes and peanuts. Crop Protection, 1 (2): 199-211. (c.f. Rev. Pl. Pathol., 6(12): 69- 73 .

El-Eraky, A.M. ; F.A. Saeed ; M.S. Mohamed and A.M. Amein (1993). Fungi associated with wheat grains in Upper Egypt and their chemical control. Assiut J. of Agric. Sci., 24(3): 245-262.

El-Fahham, Gamila, I.S. (1993). Further studies on damping-off and rootrot of lentil plants under new reclaimed soil areas. Ph.D. Thesis, Fac. Agric., Zagazig Univ., Egypt. 102p.

El-Mougy, Nehal S.A.F. (1995). Studies on wilt and root diseases of tomato in Egypt and their control by modern methods. M.sc. Thesis, Fac. Agric., Cairo UNIV., 127p.

Filippi, C.; G. Bagnoli ; M. Volterrani and G. Picci (1987). Antagonistic effects of soil bacteria on Fusarium oxysporum Schleet. F. sp. dianthi (Prill. And Dell.) Snyd. And Hans. III- Relation between protection against Fusarium wilt in carnation and bacteria antagonists colonization on roots. Plant and Soil, 98 (2): 161-167.

Garrett, S.D. (1941). The effect of plant nutrition upon disease resistance Ann. App. Biol., 28:

14.

Ghanem, A.M.M. (1998). Studies on some potato diseases and their control Ph.D. Thesis, Fac. Agric., Al-Azhar Univ., Egypt, 92p.

Grinstein, A.; Y. Elad ; j. Katan and I. Chet (1979). Control of Sclerotium rolfsii by Trichoderma harzianum in tomato plants PI. Dis. Reptr., 63: 823-826.

Hamed, S. (1996). Biocontrol of tomato root-rot disease caused by Fusarium solani with Micrococcus sp. Microbial Chemistry Department, National Research Center, Dokki, Cairo, Egypt. Proceedings of the first International Conference on Fungi; hopes and challenges, 2-5 September 1996, Cairo, Egypt. African Journal of mycology and Biotechnology, 4(2): 13-22. 
Kokalis-Burelle, N. and S.S. Gransnamanickam (2002). Biological control of tomato diseases. U.S. Horticultural Research Lab. Agricultural Research Service, U.S. Department of Agriculture, fori Pierce, Florida, U.S.A. Biological control of crop. Diseases, 255-262.

Lewis, J.A. and G.C. Papavizas (1977). Effect of plant residues on chlamydospore germination of Fusarium root-rot of beans. Phytopathology, 67:925.

Montealegre, J.; L.M. Perez; R. Herrera ; C. Santander ; J.C. Velasquez ; P. Besoain ; Y. Elad; J. Kohl and D. Steinberg (2002). Control of root-rot fungi in tomatoes with Trichoderma harzianum, Bacillus lentimorbus and solarization under glasshouse and field conditions in Chile. JOPC-WPRS Working group, Biological Control of Fungal and Bacterial Plant Pathogens: Proceedings of the $7^{\text {th }}$ Working Group Meeting, Influence of a Biotic and Biotic Factors on Biocontrol Agents at Pinc Bay, Kusadasi, Turkey, 22-25 May 2002. Bulletin-OLB-SROP, 25(10): 303-306.

Moursy, M.A. and A.A. El-Morabaa (1960). Vegetable Crops. Vol. II. Anglo-Egyptian Bookshop, Cairo, Egypt. (In Arabic).

Papavizas, G.C. and C.B. Davey (1962). Isolation and pathogenicity of $R$. solani saprophytically existing in soil. Phytopathology, 52: 834.

Papavizas, G.C.; P.B. Adams and J.A. Lewis (1968). Survival of root infecting fungi in soil V. Saprophytic multiplication of Fusarium solani f. sp. phaseoli in soil. Phytopathology, 58: 414.

Roberti, R. ; L. Ghisellini ; A. Pisi ; P. fori and G. Filippini (1993). Efficacy of two species of Trichoderma as a biological control against $R$. solani Kuhn. Isolated from string bean root-rot in Italy. Advanced in Cytochemissstry of the Mycoparasitic process. Phytopathology, 83:1062-1071 (c.f. Rev. Pl. Pathol., 73(11): 6343). 


\section{معاملة بذور الطماطم بيولوجيا لمكافحة عفن الجذور الفيوزارمي وتأثير

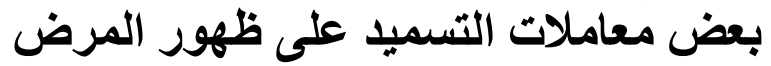

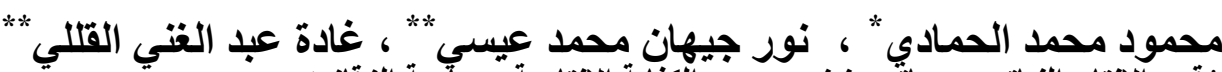

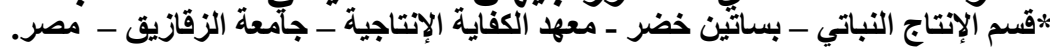
*:معهل بحوث أمراض النباتات ـ مركز البحوث الزراعية ـ الجيزة - مصر.

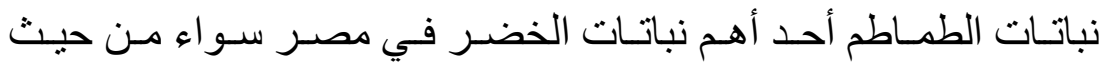

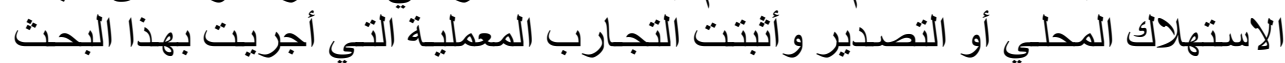

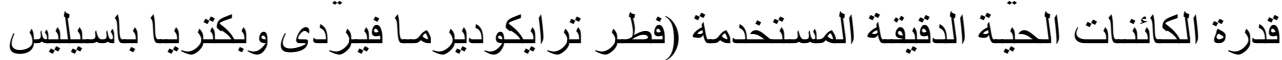

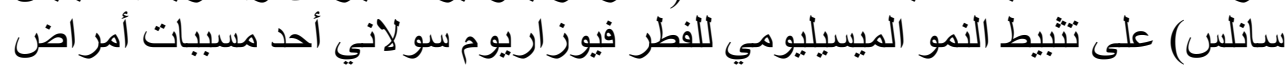

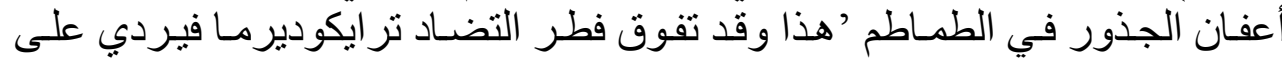
البكتيريا باسيليس سانلس في ذلإن اللك المجال. وقد أوضحت التجارب التي أجريت بالصوبة التبان والحقل أن تغطية بذور نباتات الطماطم

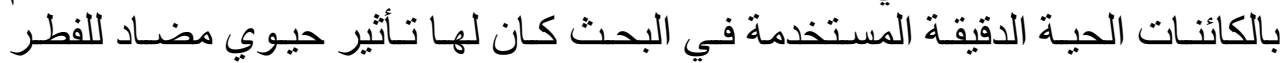

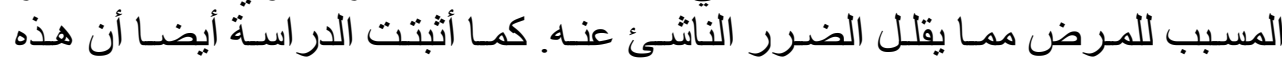

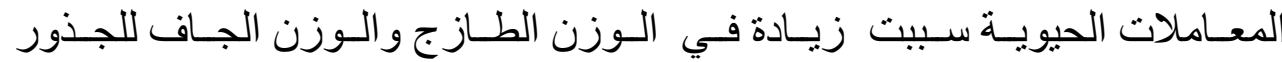

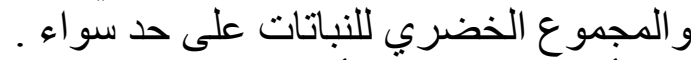

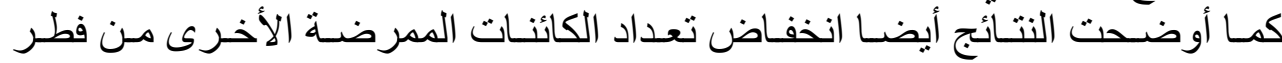

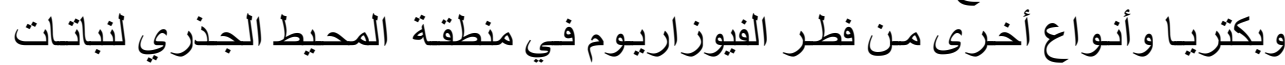

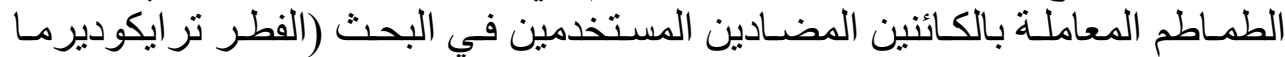
فيردي وبكتيريا باسيليس سانلس) الأنسين.

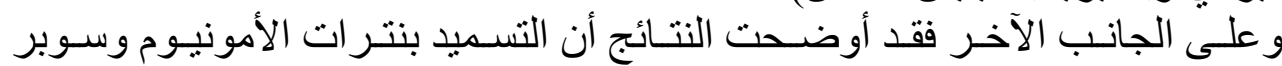

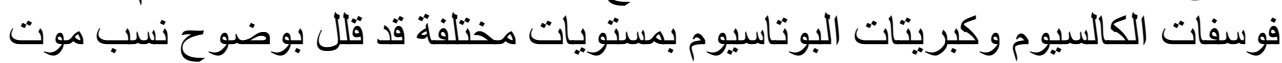

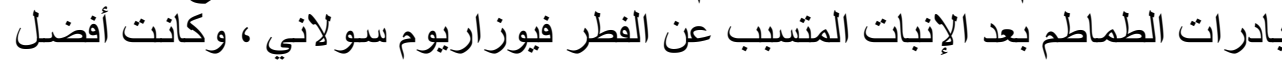
المستويات السمادية في خفض نسب الإصـابة هي

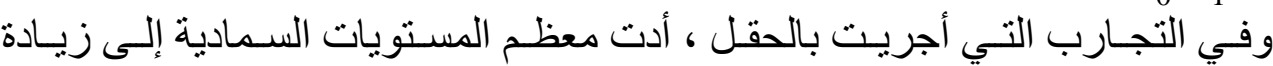

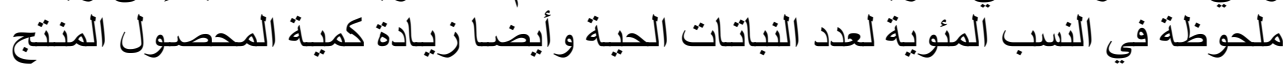

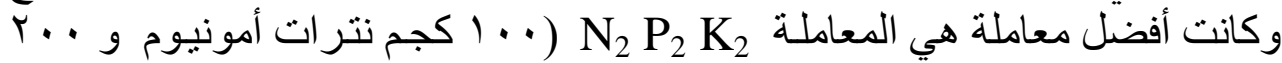

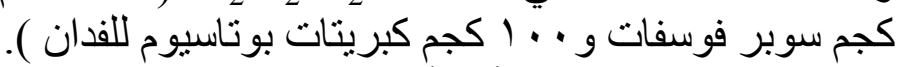

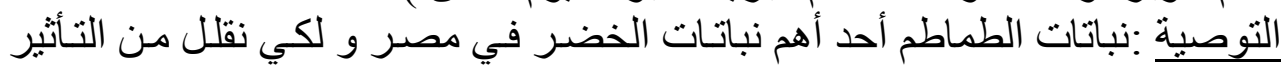

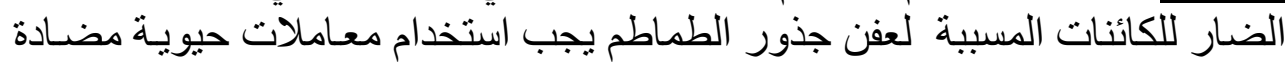

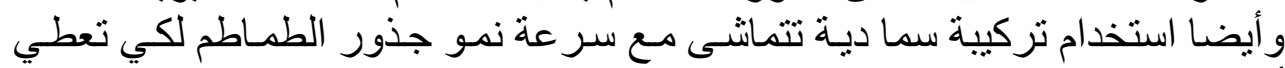

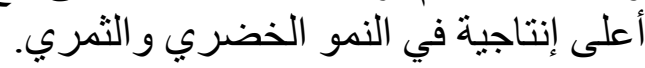

